\title{
Are Generalized Reduced Cerebrospinal Fluid Dynamics and Optic Nerve Sheath Compartmentation Sequential Steps in the Pathogenesis of Normal-Tension Glaucoma? [Response to Letter]
}

\author{
Hanspeter E Killer' \\ Achmed Pircher (D) ${ }^{2,3}$ \\ 'Department of Biomedicine, University \\ Hospital Basel \& University Basel, Basel, \\ Switzerland; ${ }^{2}$ Department of \\ Neuroscience/Ophthalmology, Uppsala \\ University, Uppsala, Sweden; \\ ${ }^{3}$ Department of Ophthalmology, \\ University Hospital Basel \& University \\ Basel, Basel, Switzerland
}

\section{Dear editor}

We appreciate the thoughtful considerations of Peter Wostyn concerning our paper Lipocalin-type prostaglandin D synthase concentration gradients in the cerebrospinal fluid in normal-tension glaucoma patients with optic nerve sheath compartmentation. ${ }^{1}$ We are aware of his many creative contributions to the field of glaucoma and neurodegeneration.

We fully agree that impaired cerebrospinal fluid (CSF) dynamics may play a crucial role in normal-tension glaucoma ${ }^{2}$ as well as in the pathophysiology of other neurodegenerative diseases, such as Alzheimer' $\mathrm{s}^{3}$ and Parkinson's disease. ${ }^{4}$ Elevated Lipocalin-type prostaglandin D-synthase (L-PGDS) levels in the lumbar CSF in our cohort of normal-tension glaucoma patients compared to the concentration measured in healthy controls in other studies might indeed indicate generalized dysfunctional CSF dynamics in patients with normal-tension glaucoma.

CSF and its content are distributed between the extracranial and the intercranial CSF spaces, eg, subarachnoid spaces, cisterns and ventricles. In order for CSF to perform its multiple functions, it also needs to be distributed within the parenchyma of the brain and the optic nerve itself. It therefore would be of great interest to know more about the concentration of proteins, such as L-PGDS, alpha synuclein and abetalipoprotein not only in the CSF surrounding the brain, but in the brain parenchyma (interstitial fluid) as well. The mechanism by which it is transported within parenchyma is still shrouded in mystery ${ }^{5}$ and should be subject of future studies.

\section{Disclosure}

The authors report no conflicts of interest in this communication.

\section{References}

Department of Neuroscience/

Ophthalmology, Uppsala University,

Uppsala, Sweden

Tel +46076496375I

Email achmed.pircher@gmail.com
1. Pircher A, Neutzner A, Montali M, et al. Lipocalin-type prostaglandin D synthase concentration gradients in the cerebrospinal fluid in normal-tension glaucoma patients with optic nerve sheath compartmentation. Eye Brain. 2021;13:89-97. doi:10.2147/EB.S297274 
2. Wostyn P, De Groot V, Van Dam D, Audenaert K, De Deyn PP. Senescent changes in 94 cerebrospinal fluid circulatory physiology and their role in the pathogenesis of 95 normal-tension glaucoma. Am J Ophthalmol. 2013;156(1):5-14. doi:10.1016/j.ajo.2013.03.003

3. Lahiri DK, Ray B. Abnormal cerebrospinal fluid (CSF) dynamics in Alzheimer's disease and normal pressure hydrocephalus: CSF-amyloid $\beta$ precursor protein metabolites as possible biomarkers. Eur $J$ Neurol. 2013;20(2):211-213. doi:10.1111/j.1468-1331.2012.03832.x
4. Murakami H, Tokuda T, El-Agnaf OMA, et al. Correlated levels of cerebrospinal fluid pathogenic proteins in drug-naïve Parkinson's disease. BMC Neurol. 2019;19(1):113. doi:10.1186/s12883-0191346-y

5. Abbott NJ, Pizzo ME, Preston JE, Janigro D, Thorne RG. The role of brain barriers in fluid movement in the CNS: is there a 'glymphatic' system? Acta Neuropathol. 2018;135(3):387-407. doi:10.1007/ s00401-018-1812-4

Dove Medical Press encourages responsible, free and frank academic debate. The content of the Eye and Brain 'letters to the editor' section does not necessarily represent the views of Dove Medical Press, its officers, agents, employees, related entities or the Eye and Brain editors. While all reasonable steps have been taken to confirm the content of each letter, Dove Medical Press accepts no liability in respect of the content of any letter, nor is it responsible for the content and accuracy of any letter to the editor.

Eye and Brain

Dovepress

\section{Publish your work in this journal}

Eye and Brain is an international, peer-reviewed, open access journal focusing on clinical and experimental research in the field of neuroophthalmology. All aspects of patient care are addressed within the journal as well as basic research. Papers covering original research, basic science, clinical and epidemiological studies, reviews and

Submit your manuscript here: https://www.dovepress.com/eye-and-brain-journal evaluations, guidelines, expert opinion and commentary, case reports and extended reports are welcome. The manuscript management system is completely online and includes a very quick and fair peerreview system, which is all easy to use. Visit http://www.dovepress. com/testimonials.php to read real quotes from published authors. 